\title{
Methylation of $23 S$ rRNA nucleotide G745 is a secondary function of the RImA' methyltransferase
}

\author{
MINGFU LIU, GUY W. NOVOTNY, ${ }^{1}$ and STEPHEN DOUTHWAITE \\ Department of Biochemistry and Molecular Biology, University of Southern Denmark, DK-5230 Odense M, Denmark
}

\begin{abstract}
Several groups of Gram-negative bacteria possess an RImA' methyltransferase that methylates 235 rRNA nucleotide G745 at the $\mathrm{N} 1$ position. Inactivation of $r \mathrm{rm} A^{\prime}$ in Acinetobacter calcoaceticus and Escherichia coli reduces growth rates by at least $30 \%$, supposedly due to ribosome malfunction. Wild-type phenotypes are restored by introduction of plasmid-encoded $r I m A^{\prime}$, but not by the orthologous Gram-positive gene $r \mathrm{Im} A^{\prime \prime}$ that methylates the neighboring nucleotide G748. Nucleotide G745 interacts with A752 in a manner that does not involve the guanine $\mathrm{N} 1$ position. When a cytosine is substituted at A752, a Watson-Crick G745-C752 pair is formed occluding the guanine N1 and greatly reducing RImA' methylation. Methylation is completely abolished by substitution of the G745 base. Intriguingly, the absence of methylation in $E$. coli rRNA mutant strains causes no reduction in growth rate. Furthermore, the slow-growing $r \operatorname{lm} A^{\prime}$ knockout strains of Acinetobacter and $E$. coli revert to the wild-type growth phenotype after serial passages on agar plates. All the cells tested were pseudorevertants, and none of them had recovered G745 methylation. Analyses of the pseudorevertants failed to reveal second-site mutations in the ribosomal components close to nucleotide G745. The results indicate that cell growth is not dependent on G745 methylation, and that the RImA' methyltransferase therefore has another (as yet unidentified) primary function.
\end{abstract}

Keywords: rRNA methylation; RNA methyltransferase; ribosome tunnel

\section{INTRODUCTION}

All living organisms modify their stable RNAs post-transcriptionally, and to date almost one hundred different types of nucleotide modification having been reported (Rozenski et al. 1999). In bacteria, each rRNA modification is generally the product of a specific enzyme, contrasting with the mechanisms in eukaryal cells where numerous modifications are guided by a variety of snoRNAs that function together with a limited set of enzymes (Kiss 2002; Ofengand 2002; Decatur and Fournier 2003). Whatever the mechanism involved, any nucleotide modification will have a finite energetic cost, and thus each rRNA modification might be expected to prove its worth by performing a distinct function. Several nucleotide modifications in rRNA have indeed been shown to be important for translation (Green and Noller 1996), and a number of additional modifications provide advantageous phenotypic traits under particular

Reprint requests to: Stephen Douthwaite, Department of Biochemistry and Molecular Biology, University of Southern Denmark, DK-5230 Odense M, Denmark; e-mail: srd@bmb.sdu.dk; fax: (+45) 65502467.

${ }^{1}$ Present address: Dept. Growth and Reproduction, Copenhagen University, Rigshospitalet, DK-2100 Copenhagen, Denmark.

Article published online ahead of print. Article and publication date are at http://www.rnajournal.org/cgi/doi/10.1261/rna.7820104. conditions, such as conferring resistance against ribosometargeting antibiotics (Cundliffe 1989; Weisblum 1995; Mankin 2001). However, the functions of most rRNA modifications are far from fully understood. Moreover, there is a small but growing number of reports of rRNA modifying enzymes that are necessary for efficient cell growth while the products of these enzymes, the nucleotide modifications, appear to be superfluous (Persson et al. 1992; Lafontaine et al. 1998; Gutgsell et al. 2001).

The rRNA modifications in Esherichia coli are the best characterized of any species (Rozenski et al. 1999). The E. coli $16 \mathrm{~S}$ and $23 \mathrm{~S}$ rRNAs contain 11 and 23 modifications respectively, and in many cases the enzymes responsible for these modifications are known. Several classes of Gramnegative bacteria, including E. coli, are methylated at the conserved nucleotide G745 in domain II of 23S rRNA (Fig. 1) by the methyltransferase enzyme $R \operatorname{lmA}{ }^{\mathrm{I}}$ (formerly RrmA) (Gustafsson and Persson 1998; Liu and Douthwaite 2002a). Some Gram-positive species possess an orthologous methyltransferase, $\mathrm{RlmA}^{\mathrm{II}}$ (formerly TlrB), which methylates the neighboring and similarly conserved nucleotide G748 (Liu and Douthwaite 2002a), and confers resistance to the macrolide antibiotic tylosin (Fouces et al. 1999; Wilson and Cundliffe 1999; Liu and Douthwaite 2002b). Methylation at G745 does not confer antibiotic resistance, and 

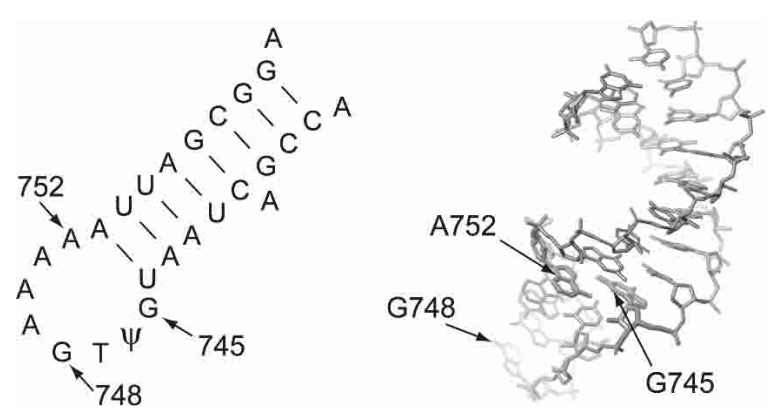

FIGURE 1. (Left panel) Secondary structure of the E. coli $23 \mathrm{~S}$ rRNA stem-loop containing the target nucleotides for the $\mathrm{R} \operatorname{lm} \mathrm{A}^{\mathrm{I}}$ and $\mathrm{R} \operatorname{lm} \mathrm{A}^{\mathrm{II}}$ methyltransferases at G745 and G748, respectively. Base substitutions were made at G745 and A752 by site-directed mutagenesis. The Acinetobacter rRNA has essentially the same sequence. (Right panel) Tertiary fold of same stem-loop determined by NMR (Lebars et al. 2003); the structure is an average of the 17 coordinate sets in the database file. The sheared base pair between G745 and A752 is evident. The N-1 of G745 is oriented toward the RNA major groove; the N-1 of G748 is more readily accessible at the tip of the hairpin loop. The structure of the E. coli $\mathrm{RlmA}{ }^{\mathrm{I}}$ has recently been solved, and a mechanism of substrate recognition has been proposed (Das et al. 2004).

although the exact function of $\mathrm{RlmA}^{\mathrm{I}}$ is less clear, it has been shown that inactivation of the E. coli $r \operatorname{lm} A^{I}$ gene reduces the efficiency of protein synthesis and concomitantly lowers growth rates (Gustafsson and Persson 1998).

In the course of using several different $E$. coli strains in which the $r \operatorname{lm} A^{I}$ genes had been inactivated (Björk and Isaksson 1970; Gustafsson and Persson 1998; Liu and Douthwaite 2002c), we observed that the slow-growth phenotype tended to be spontaneously lost on continual replating and regrowth of cultures. The resultant cells were all pseudorevertants that had regained the wild-type growth rate without restoring methylation at G745. It was not immediately clear to us whether we were observing a phenomenon peculiar to E. coli, or whether these results indicated that the $\mathrm{R} \operatorname{mm} \mathrm{A}^{\mathrm{I}}$ class of methyltransferases had a more important function that the modification of G745.

Here, we investigate the importance of G745 methylation for cell growth by blocking $\mathrm{RlmA}^{\mathrm{I}}$ activity in two independent ways. First, the $\operatorname{rm} A^{I}$ gene was inactivated in another bacterial model; and second, methylation was blocked by altering the structure of the rRNA substrate at nucleotide G745. For the first study, the Gram-negative bacterium Acinetobacter was chosen as methylation of its rRNA at G745 (Liu and Douthwaite 2002a) indicated that it possesses an $r \operatorname{lm} A^{I}$ gene, and because this bacterium is suitably phylogenetically distant from E. coli to be able to make a comparison of the RlmA ${ }^{\mathrm{I}}$ methyltransferases worthwhile. We identified the Acinetobacter $\operatorname{rm} A^{I}$ prior to inactivating the gene within the original strain and evaluating how this affected cell growth. We then attempted to rescue the original Acinetobacter growth characteristics by introducing homologous $r m A^{I}$ and orthologous $r \operatorname{lm} A^{I I}$ genes on plasmids, and also by selecting for spontaneous revertant strains. In parallel experiments, we mutagenized the rRNA target to pre- vent methylation of nucleotide 745 in $E$. coli strains that possess an authentic and active copy of $r m A^{I}$. These studies conclusively show that methylation at G745 is not required to maintain grow rates, and is thus not the primary function of the $\operatorname{Rlm} A^{\mathrm{I}}$ methyltransferase.

\section{RESULTS AND DISCUSSION}

\section{Cloning of Acinetobacter $\operatorname{rm} A^{\prime}$}

In this study, we investigate the function of the $\mathrm{R} \operatorname{lm} \mathrm{A}^{\mathrm{I}}$ methyltransferase that modifies 23S rRNA nucleotide G745 in several groups of Gram-negative bacteria. There is a high degree of similarity between $\mathrm{Rlm} \mathrm{A}^{\mathrm{I}}$ and the orthologous methyltransferase $\mathrm{RlmA}{ }^{\mathrm{II}}$, which modifies the neighboring nucleotide G748 in Gram-positive species (Liu and Douthwaite 2002a). Both classes of enzyme methylate at the $\mathrm{N} 1$ position of their respective guanine targets (Douthwaite et al. 2004).

Alignment of previously characterized $\mathrm{RlmA} \mathrm{A}^{\mathrm{I}}$ and $\mathrm{R} \operatorname{lm} \mathrm{A}^{\mathrm{II}}$ sequences (Bujnicki et al. 2002; Liu and Douthwaite 2002a) revealed two suitably spaced blocks of conserved amino acids: CGEGYY in the N-terminal region, corresponding to domain I of the methyltransferase S-adenosylmethionine binding site (Kagan and Clarke 1994); and MTPF/yA/gW within the methyltransferase $\mathrm{C}$-terminal sequence. The primers $\mathrm{mf51}$ and $\mathrm{mf52}$, respectively corresponding to these amino acid sequences, gave a PCR product of approximately 450 bp from the Acinetobacter chromosome template, fitting with the expected sequence and size of an $r \operatorname{lm} A^{I}$ gene fragment. This fragment (cloned in plasmid pSD50) was used to probe Southern blots of Acinetobacter genomic DNA, and the intact $r \operatorname{lm} A^{I}$ gene was found in a HindIII fragment $(\sim 2.6 \mathrm{~kb})$, which was subsequently cloned into plasmid pSD82 (Table 1).

The coding region Acinetobacter $r \operatorname{lm} A^{I}$ is 828 bp long, corresponding to a protein of 275 amino acids. As was expected, the putative protein is more closely related to $\mathrm{RlmA}^{\mathrm{I}}$ proteins from Gram-negative bacteria than to $\mathrm{RlmA}^{\mathrm{II}}$ from Gram-positives, and shows $41 \%$ identity (51\% similarity) with E. coli $\mathrm{RlmA} \mathrm{I}^{\mathrm{I}}$, compared to $31 \%$ identity (39\% similarity) with Streptomyces fradiae $\mathrm{RlmA}{ }^{\mathrm{II}}$. The 1002 bp sequence of the Acinetobacter $r l m A^{I}$ gene with its promoter and terminator has been deposited in the GenBank (accession number AY029296).

\section{The Acinetobacter RImA' methylates $23 \mathrm{~S}$ rRNA nucleotide G745}

The Acinetobacter $\mathrm{RlmA}^{\mathrm{I}}$ protein was expressed in E. coli and purified to over $95 \%$ homogeneity, as estimated by SDS-PAGE mini-gel electrophoresis. This protein was then incubated with $23 \mathrm{~S}$ rRNAs from Acinetobacter ASD89 and E. coli IB10 both of which lack methylation at nucleotide G745. Primer extension analysis showed that the Acineto- 
TABLE 1. Bacterial strains, plasmids and oligodeoxynucleotide primers

\begin{tabular}{|c|c|c|}
\hline & Description & Reference \\
\hline \multicolumn{3}{|l|}{ Strains } \\
\hline $\begin{array}{l}\text { Acinetobacter calcoaceticus } \\
\text { ADP1 }\end{array}$ & Wild type & Juni 1972 \\
\hline $\begin{array}{l}\text { A. calcoaceticus } \\
\text { ASD89 }\end{array}$ & Derived from ADP1: $r / m A^{l}, \operatorname{Kan}^{\mathrm{R}}$ & This study \\
\hline Escherichia coli & 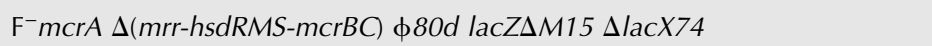 & Life \\
\hline DH10B & deoR recA1 endA1 araD139 $\Delta($ ara, leu 7697 galU galK $\lambda r p s L$ nupG & Technologies, Inc. \\
\hline E. coli IB10 & thr leu his argA relA rrmA10 & Björk and Isaksson 1970 \\
\hline E. coli TA531 & $\begin{array}{l}\Delta(r r n E r r n B \text { rrnH } r r n A) r r n G:: \text { LacZ }^{+} r r n D:: \text { cat }^{+} r r n C:: \text { cat }^{+} \Delta r e c A / p T R N A 66, \\
\text { pHK-rrnC }\end{array}$ & Asai et al. 1999 \\
\hline \multicolumn{3}{|l|}{ Plasmids } \\
\hline pHK-rrnC & $\begin{array}{l}\text { Contains the entire, wild-type } E \text {. coli } r r n C \text {; used to maintain } E \text {. coli strain } \\
\text { TA531: } \operatorname{Kan}^{R}\end{array}$ & Asai et al. 1999 \\
\hline pNK & Contains the entire, wild-type $E$. coli $r r n B: \mathrm{Amp}^{\mathrm{R}}$ & Xiong et al. 2000 \\
\hline pSD50 & Acinetobacter $r / m A$ fragment cloned in pUC19 at Hincll: $A_{m p}^{R}$ & This study \\
\hline pSD82 & $\begin{array}{l}\text { Acinetobacter HindlII genome fragment with complete } r / m A^{\prime} \text { sequence; } \\
\text { cloned in pUC19: Amp }{ }^{R}\end{array}$ & This study \\
\hline pSD88 & Acinetobacter rlmAl gene cloned in pUHE24-2 at NedI/BgIII: Amp ${ }^{R}$ & This study \\
\hline pSD88-KanR & Disruption of pSD88 $r / m A^{\prime}$ gene at Eco47III: $\mathrm{Amp}^{\mathrm{R}}, \mathrm{Kan}^{\mathrm{R}}$ & This study \\
\hline pSD114 & Streptomyces fradiae $r I m A^{\prime \prime}(t / r B)$ gene cloned in $\mathrm{pWH} 845: \mathrm{Amp}^{\mathrm{R}}$, lac ${ }^{q}$ & This study \\
\hline pSD118 & $\begin{array}{l}\text { Corynebacterium glutamicum pAG1 rlmA" gene cloned in pWH845: } \\
\mathrm{Amp}^{\mathrm{R}}, \mathrm{lacl}^{q}\end{array}$ & This study \\
\hline pSD189 & Acinetobacter $r \mathrm{~mA}^{\prime}$ gene cloned in $\mathrm{pWH} 845: \mathrm{Amp}^{\mathrm{R}}$, laclq & This study \\
\hline pUC19 & Cloning/sequencing vector: $A m p^{R}$ & Yanisch-Perron et al. 1985 \\
\hline pUHE24-2 & Cloning/expression vector: $\mathrm{Amp}^{\mathrm{R}}$ & Bujard et al. 1987 \\
\hline pWH845 & Acinetobacter/E.coli shuttle vector: $\mathrm{Amp}^{\mathrm{R}}$, laclq & Schirmer et al. 1997 \\
\hline
\end{tabular}

bacter $\mathrm{RlmA} \mathrm{A}^{\mathrm{I}}$ methylated G745 in both $23 \mathrm{~S}$ rRNAs in vitro by a mechanism that is dependent on the methyl donor S-adenosylmethionine (data not shown).

The knockout experiment confirmed that Acinetobacter $\mathrm{R} \operatorname{lm} \mathrm{A}^{\mathrm{I}}$ carries out the same G745 methylation reaction in vivo. The chromosomal DNA of six randomly chosen Acinetobacter $\mathrm{Kan}^{\mathrm{R}}$ recombinants gave rise to a $2-\mathrm{kb}$ PCR product $\left(0.8 \mathrm{~kb} r \operatorname{lm} A^{I}+1.2-\mathrm{kb} \mathrm{Kan}^{\mathrm{R}}\right.$ cassette). Reverse transcriptase primer extension showed that G745 was no longer methylated in any of these strains.

\section{Slow growth of the Acinetobacter $\operatorname{rm} A^{\prime}$ knockout}

Inactivation of the $\operatorname{rm} A^{I}$ gene caused a significant reduction in the growth rate of Acinetobacter on agar plates. The doubling time of one of the knockout clones, ASD89, was measured to be $39 \mathrm{~min}$ in liquid medium, versus $30 \mathrm{~min}$ for the wild-type strain grown under the same conditions. Comparable growth retardation has been observed after inactivation of $r \operatorname{lm} A^{I}$ in E. coli (Gustafsson and Persson 1998).

Plasmid-encoded $r \operatorname{lm} A^{I}$ genes from E. coli and Acinetobacter and $r l m A^{I I}$ genes from Streptomyces fradiae and Corynebacterium glutamicum (Table 1) were expressed in Acinetobacter ASD89, and methylated $>95 \%$ of the 23S rRNA molecules at the respective G745 and G748 targets (not shown). The growth defect of Acinetobacter ASD89 was cor- rected by both the $\operatorname{rm} A^{I}$ genes, but not by either of the orthologous $r \operatorname{lm} A^{I I}$ genes. The successful rescue by plasmidencoded $r \operatorname{lm} A^{I}$ matches an earlier observation for $E$. coli (Gustafsson and Persson 1998), and shows that the slow growth phenotype of the knockout strains was not caused by co-disruption of some other chromosomal gene. We note in this context that $\operatorname{rm} A^{I}$ is tightly flanked on the Acinetobacter chromosome by the penicillin-binding transpeptidase gene. It is unclear whether this arrangement is significant, although it is similar to that in Salmonella enterica and Streptomyces fradiae, where the $\operatorname{rm} A$ gene is within 13 to $360 \mathrm{bp}$ of the gene for cell wall synthesis.

\section{Spontaneous reversion from the slow grow phenotype}

The slower growth of E. coli $\operatorname{rlm} A^{I}$ knockouts was previously thought to reflect the requirement for methylation at nucleotide G745. While this idea is consistent with many observations, including the inability of G748 methylation to rescue the $\operatorname{rm} A^{I}$ defect, it does not fit with a closer analysis of revertant strains. The growth defect of the Acinetobacter $\operatorname{rm} A^{I}$ knockout was lost during serial passaging of the strain on agar plates, consistent with our observations for $E$. coli $\operatorname{rm} A^{I}$ knockouts. The reversion to wild-type growth rate is a spontaneous event, and no slow growing Acinetobacter colonies were observed at the fourteenth passage. None of 
the Acinetobacter or E. coli cells tested had regained their ability to methylate G745, and all were thus pseudorevertants.

The pseudorevertants offer a potential means of elucidating the function of RlmA ${ }^{\mathrm{I}}$ and G745 methylation. From the ribosome crystal structures (Ban et al. 2000; Harms et al. 2001; Yusupov et al. 2001), the N1 group of G745 can be seen to intrude into a narrow region of the subunit tunnel that is involved in the gating of peptides (Nakatogawa and Ito 2002; Tenson and Ehrenberg 2002), and is adjacent to the macrolide antibiotic binding site (Schlünzen et al. 2001; Hansen et al. 2002). Thus, it was tempting to speculate that the methylation state of G745 could play a role in one or more of these processes. We therefore took two of the E. coli pseudorevertants (in preference to Acinetobacter, for which the genome is not yet known) and sequenced the genes for the ribosomal components that are situated close to G745. However, we found no second-site mutations in any of these components, including the rRNA sequences surrounding nucleotides G745 and A2058, and the r-proteins L4 and L22, which have been shown to influence the subunit structure close to G745 (Gregory and Dahlberg 1999; Gabashvili et al. 2001).

\section{Mutagenizing the rRNA target for $\operatorname{RImA}^{\mathbf{I}}$}

In a final series of experiments, we prevented $R \operatorname{lm} A^{I}$ methylation by mutagenizing its rRNA target site. The RlmA methyltransferase modifies its substrate before the rRNA associates with the r-proteins to assemble into functional 50S subunits (Hansen et al. 2001). The structure of this RNA region, in the conformation that is recognized by the methyltransferase, has been solved by NMR (Lebars et al. 2003) and shows that G745 and A752 stack onto helix 35 to form an irregular, noncanonical base pair, which does not involve the N1 position of G745 (Fig. 1). Single base substitutions were introduced in the E. coli 23S rRNA gene and were expressed in E. coli strain TA531 (Table 1), which enabled us to observe the phenotypes conferred by homogeneous populations of mutant ribosomes. TA531 cells with the mutant rRNAs were all kanamycin sensitive, indicating that the original plasmid with the wild-type $r m C$ operon had been lost. Furthermore, direct sequencing of the rRNA verified that ribosomes contained only mutant $23 \mathrm{~S}$ rRNA encoded by the pNK-encoded $r r n B$ operon.

From the NMR structure (Fig. 1), substitution of guanine or uracil at nucleotide 752 would not be expected to decrease the accessibility of G745. Accordingly, methylation in vivo by $R \operatorname{lmA} A^{\mathrm{I}}$ remains complete in the $752 \mathrm{G}$ and $752 \mathrm{U}$ mutants (Fig. 2). Similarly, mild alteration of the RNA loop conformation by deletion of one of the adenosines between 749 and 753 had no detectable effect on in vivo methylation, nor was any effect on RlmA ${ }^{\mathrm{I}}$ methylation observed after substitution of nucleotide 748. However, methylation by $\mathrm{R} \operatorname{lm} \mathrm{A}^{\mathrm{I}}$ was greatly reduced by introduction of a cytosine at position 752 (Fig. 2). This latter effect is presumably due to
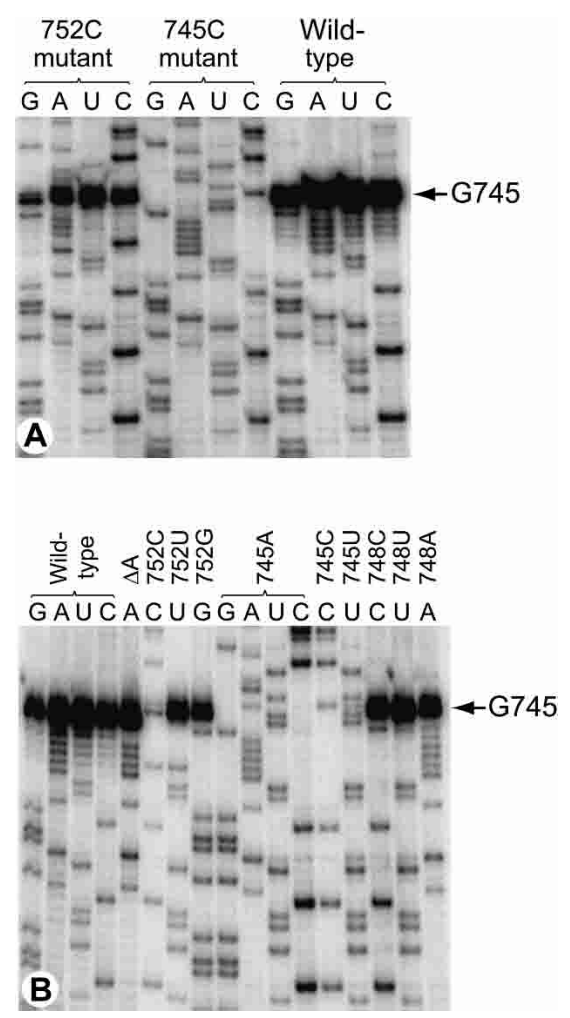

FIGURE 2. Gel autoradiographs showing the effects of rRNA mutations on methylation at nucleotide 745 by $\mathrm{RlmA}^{\mathrm{I}}$. Mutant and wildtype rRNAs were extracted from E. coli strain TA531 that contains an active $R \operatorname{lmA}{ }^{\mathrm{I}}$ methyltransferase, and were sequenced by reverse transcriptase extension from the mf11 primer. Methylation at the G745 N1 aborts reverse transcription. (A) All four sequencing reactions for the wild-type strain ( $98 \%$ of the rRNA molecules were methylated); for the $752 \mathrm{C}$ mutant (14\% methylation); and for the $745 \mathrm{C}$ mutant (zero methylation). (B) Selected sequencing reactions (horizontal letters above the lanes) from the other mutant rRNA strains discussed in the text (vertical labeling). $\Delta \mathrm{A}$, deletion of one of the adenosines between 749 and 753 .

the formation of a Watson-Crick G-C pair, which engages the N1 proton of G745 in a hydrogen bond. Methylation was completely abolished after removal of the $\mathrm{RlmA}^{\mathrm{I}}$ target base by substitutions at G745.

Despite the loss of methylation (and the loss of phylogenetically conserved bases), none of the substitutions at positions 745 and 752 altered the growth rate of E. coli, which was consistently around $57 \mathrm{~min}$ (with a standard deviation of $\pm 3.5 \mathrm{~min}$ ) under the growth conditions used. The phenotypes of these rRNA mutants assuage our lack of success at identifying second-site mutations in the ribosomal components of the pseudorevertants. The putative second-site mutations are possibly not rescuing the lack of G745 methylation, but are perhaps compensating for some other function of RlmA $A^{I}$.

\section{Alternative function for $\operatorname{RIm}^{\mathbf{I}}$}

There are other reports of enzymes that modify stable RNAs while presumably having another, more important, func- 
tion. Two such examples of methyltransferases are TrmA in E. coli that is specific for 5-methylation of U54 in tRNA (Persson et al. 1992), and yeast Dimlp that dimethylates the N6 of both A1779 and A1780 in 18S rRNA (Lafontaine et al. 1998). Both methyltransferases are essential for cell viability, whereas the modifications they carry out are dispensable. This type of phenomenon is not limited to methyltransferases, and has also been observed for RluD, an enzyme that converts three uridines in E. coli $23 \mathrm{~S}$ rRNA to pseudouridines. Knocking out $r l u D$ expression adversely affects growth, whereas point mutations in $r l u D$ that allow RluD expression while abolishing its pseudouridine synthetase activity do not appear to have a detrimental effect (Gutgsell et al. 2001).

Our rRNA mutagenesis study closely parallels that of RluD: In both studies, cells express a full length and (presumably) correctly folded modification enzyme which fails to modify its substrate, either because of a substitution in the active site of the enzyme (RluD) or a substitution in the rRNA substrate (this study). As in the RluD study, we conclude that rRNA modification is a secondary function of the enzyme under investigation. The primary functions of these enzymes are most likely ribosome-related, and the involvement of $\mathrm{RlmA}^{\mathrm{I}}$ in a chaperone-like role aiding ribosome assembly, as has been suggested for RluD (Gutgsell et al. 2001), remains a strong possibility.

\section{MATERIALS AND METHODS}

\section{Bacterial strains, plasmids, and growth conditions}

All the strains and plasmids employed in this study are listed in Table 1. Acinetobacter and E. coli strains were grown at $37^{\circ} \mathrm{C}$ in $\mathrm{LB}$ medium (Sambrook et al. 1989). For transformation of Acinetobacter, cells were cultured in minimal medium (Juni 1972) supplemented with $10 \mathrm{mM}$ succinate. E. coli strain DH10B was used for recombinant work including protein expression. Plasmid pUC19 was used for cloning of PCR products to identify the Acinetobacter $r m A^{I}$ gene, and as the vector for site-directed mutagenesis of $E$. coli $23 \mathrm{~S}$ rRNA gene fragments. The complete Acinetobacter $r \mathrm{r}^{I}$ gene was cloned and expressed in plasmid pUHE24-2; mutant $23 \mathrm{~S}$ rRNAs were expressed within their original $\mathrm{rrnB}$ context in plasmid pNK. Plasmid pWH845 was used for expressing various $r l m A^{I}$ and $\operatorname{rm} A^{I I}$ genes in the Acinetobacter $\operatorname{rlm} A^{I}$ knock-out strain, and as a shuttle vector between Acinetobacter and E. coli. Where appropriate, the antibiotic ampicillin was used at a concentration of $100 \mu \mathrm{g} / \mathrm{ml}$ for E. coli, and at $300 \mu \mathrm{g} / \mathrm{ml}$ for Acinetobacter; kanamycin was used at $25 \mu \mathrm{g} / \mathrm{ml}$ for both bacteria.

Phenotypes conferred by the different mutant rRNAs were evaluated in E. coli strain TA531. All the seven chromosome-coded rRNA ( $r r n$ ) operons have been disrupted in TA531 (Asai et al. 1999); rRNA production in this strain is dependent on plasmidencode $r r n$ that is initially provided on $\mathrm{pHK}-\mathrm{rrnC}^{+}$and subsequently on pNK-derivatives with mutant $r r n B$. For cell growth rate determinations, one thousand-fold dilutions of overnight cultures were grown in Luria broth with the appropriate antibiotics, and cell densities were followed at $\mathrm{OD}_{600}$.

\section{DNA manipulations}

Acinetobacter chromosomal DNA was isolated essentially as described for E. coli (Sambrook et al. 1989). Standard DNA techniques were employed for plasmid DNA isolation, DNA manipulations and E. coli transformation (Sambrook et al. 1989). Acinetobacter was transformed by exploiting the natural competency of the bacterium (Palmen et al. 1993). Plasmid DNA was sequenced using the CEQ 2000 DNA Analysis System (Beckman), primered from the vector or within the gene. Restriction enzymes, ligase and Pwo polymerase (Roche Molecular Biochemicals) and AMV reverse transcriptase (Finnzymes) were used according to the suppliers' recommendations.

\section{Identification and cloning of the Acinetobacter $r \operatorname{lm} A^{\prime}$ gene}

Two degenerate PCR primers, mf51 and mf52 (Table 2), were designed based on the sequences of previously characterized

TABLE 2. Oligodeoxynucleotide primers used in this study

\begin{tabular}{|c|c|c|}
\hline Primer name & Sequence & Application \\
\hline-21 & 5'-AACAGCTATGACCATG & Binds after the $3^{\prime}$ end of the pUC19 polycloning site \\
\hline-40 & 5'-GTTTTCCCAGTCACGAC & Binds in front of the $5^{\prime}$ end of the pUC19 polycloning site \\
\hline gwn1 to gwn6 & 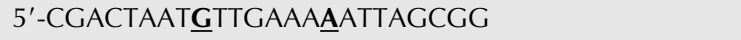 & Mutagenesis $^{\mathrm{a}}$ of G745 and A752 \\
\hline gwn11 to gwn16 & 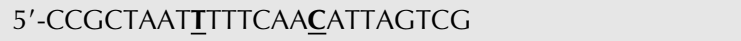 & Mutagenesis ${ }^{a}$ of G745 and A752 \\
\hline mf11 & 5'-TTTCGGGGAGAACCAGCTA & Primer extension from 23S rRNA nucleotides 800 to 817 \\
\hline mf51 & 5'-TGYGGNGARGGNTAYTAY & Degenerate PCR primer ${ }^{\mathrm{b}} \mathrm{r} / m A^{\prime}$ \\
\hline mf52 & 5'-CCANGCRWANGGNGTCAT & Degenerate PCR primer ${ }^{\mathrm{b}} \mathrm{r} / m A^{\prime}$ \\
\hline mf71 & $\begin{array}{l}\text { 5'-TAACACTCATATGcatcaccatcaccatcac } \\
\text { AATGTGTTGATGTGCССTGTG }\end{array}$ & $\begin{array}{l}\text { 5'-end } r / m A^{\prime} \text { with } \mathrm{Ndel} \text { site (underlined) plus } 6 \mathrm{xH} \text { is tag } \\
\text { (small-case) }\end{array}$ \\
\hline $\mathrm{mf} 72$ & 5'-GCAGAAGCTTCACTGGAAGGATTGATTAATCAAGTGA & $3^{\prime}$-end $r \operatorname{lm} A^{\prime}$ with HindIII site (underlined) \\
\hline sd33 & 5'-CATCCGCTAATTTTTTC & Complementary to $23 \mathrm{~S}$ sequence $748-763$ \\
\hline
\end{tabular}

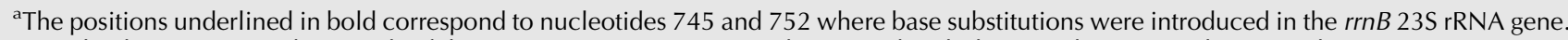
A single change was made in each of the $5^{\prime}$-mutagenesis primers and was used with the complementary change in the $3^{\prime}$-primer.

${ }^{b} \mathrm{~N}=\mathrm{G} / \mathrm{A} / \mathrm{T} / \mathrm{C} ; \mathrm{Y}=\mathrm{C} / \mathrm{T} ; \mathrm{R}=\mathrm{A} / \mathrm{G} ; \mathrm{W}=\mathrm{A} / \mathrm{T}$. 
$\mathrm{R} \operatorname{lm} \mathrm{A}^{\mathrm{I}}$ and $\mathrm{R} \operatorname{lm} \mathrm{A}^{\mathrm{II}}$ proteins. PCR reactions on Acinetobacter chromosomal DNA using $\mathrm{mf51}$ and $\mathrm{mf52}$ (annealing temperature $50^{\circ} \mathrm{C}$ ) gave rise to a main product of approximately $450 \mathrm{bp}$, which was then ligated into the HincII site of pUC19. The first three plasmid clones that were sequenced contained the same fragment, and this was homologous to known $\operatorname{rm} A$ sequences (Bujnicki et al. 2002; Liu and Douthwaite 2002a); one plasmid clone (dubbed pSD50) was used for further study.

Acinetobacter chromosomal DNA was digested with BamHI, EcoRI, HindIII, XbaI, and XhoI, and was run in duplicate sets on a $0.7 \%$ agarose gel. The one set of DNA digestion products was denatured, blotted to Zeta-Probe Membrane (Bio-Rad) and probed under stringent conditions (Sambrook et al. 1989) with the ${ }^{32} \mathrm{P}$-labeled insert from pSD50. Signal bands in the XbaI and HindIII lanes were used to locate the corresponding gel bands in the second set of digestion products, which were then extracted using a gel purification kit (Qiagen) and cloned into the respective restriction sites in pUC19. Recombinants were screened by colony hybridization using the same pSD50 probe, and positive clones were sequenced.

The complete Acinetobacter $\operatorname{rm} A^{I}$ gene was identified in plasmid pSD82 that contained a HindIII fragment. The Acinetobacter $\operatorname{rlm} A^{I}$ gene was lifted out of pSD82 by PCR using primers $\mathrm{mf} 71$ and $\mathrm{mf} 72$ (annealing temperature $55^{\circ} \mathrm{C}$ ), which correspond to the $5^{\prime}$ - and $3^{\prime}$-ends of the gene and encode NdeI and HindIII sites, respectively; $\mathrm{mf7} 1$ additionally includes the code for a histidine tag. The PCR product of slightly less than $900 \mathrm{bp}$ was inserted into the NdeI/HindIII sites of the expression vector pUHE24-2. The first three plasmids analyzed contained the correct Acinetobacter $r \operatorname{lm} A^{I}$ sequence, and one plasmid (pSD88) was taken for further study.

\section{Insertional inactivation of the Acinetobacter chromosomal $r \operatorname{lm} A^{\prime}$ gene}

A kanamycin resistance gene cassette was inserted into the Eco47III site of the pSD88 $r m A^{I}$ gene, creating plasmid pSD88$\mathrm{Kan}^{\mathrm{R}}$. The latter plasmid was linearized and used to transform Acinetobacter ADP1. Cells were selected on plates containing kanamycin, and $\operatorname{Kan}^{\mathrm{R}} \operatorname{rlm} A^{I}$ knock-out candidates were screened by PCR using the mf71 and mf72 primers. The loss of methylation at nucleotide G745 in knock-out clones was verified by primer extension from the $23 \mathrm{~S}$ rRNA primer $\mathrm{mfl} 1$, and one Acinetobacter clone that passed all the screening criteria was called ASD89.

\section{Expression of $r \operatorname{Im} A^{\prime}$ and $r \operatorname{Im} A^{\prime \prime}$ genes in Acinetobacter ASD89}

The $r \operatorname{lm} A^{I}$ genes from E. coli (Hansen et al. 2001) and Acinetobacter, and the $\operatorname{rm} A^{I I}$ genes from Streptomyces fradiae and Corynebacterium glutamicum (Liu and Douthwaite 2002a) were cloned in plasmid pWH845 (Table 1). The pWH845-encoded methyltransferases were expressed in Acinetobacter ASD89, and the degree of methylation at nucleotides G745 or G748 was assessed by reverse transcriptase analysis of the $23 \mathrm{~S}$ rRNA (method description below).

\section{$R \operatorname{lm} A^{\prime}$ protein purification and activity}

The N-terminal histidine-tagged Acinetobacter $\mathrm{RlmA}^{\mathrm{I}}$ protein was expressed from plasmid pSD88 in E. coli and was purified by nickel ion affinity chromatography (Qiagen). Total RNA from Acinetobacter ASD89 and E. coli IB10 was isolated using RNeasy mini kit (Qiagen). The action of RlmA ${ }^{\mathrm{I}}$ on unmethylated $23 \mathrm{~S}$ rRNA substrates from these strains was investigated in vitro as previously described (Liu et al. 2000).

\section{Site-directed mutagenesis of $E$. coli rRNA}

Nucleotides 745 and 752 in the E. coli rrnB 23S rRNA gene were mutagenized by PCR using two sets of oligonucleotides (Higuchi et al. 1988; Ho et al. 1989). Briefly, the $900 \mathrm{bp} \mathrm{SacI/SphI} \mathrm{fragment}$ from domain II of the $r r n B$ 23S rRNA gene was inserted into the same sites of plasmid pUC19. Complementary oligonucleotide primers containing the desired rRNA mutations were designed (Table 1), and each was used in separate PCR reactions with the -21 and -40 primers that bind outside the SacI and the SphI sites in pUC19. The products from the first two reactions were mixed in a second PCR reaction to regenerate the 900 fragment, which was cloned back into pUC19. The SacI/SphI fragment was sequenced in plasmid clones, and those containing the desired mutations were inserted into the original $\mathrm{rrnB}$ context in plasmid pNK.

\section{Expression of mutant 23S rRNAs}

The pNK plasmid-derivatives were moved into E. coli strain TA531. Cells were grown for at least twenty generations in LB medium containing ampicillin, before being diluted $10^{5}$-fold and plating onto agar with ampicillin. Individual colonies were screened for loss of kanamycin resistance, which indicated displacement of the resident plasmid $\mathrm{pHK}-\mathrm{rrnC}^{+}$by a $\mathrm{pNK}$-derivative. As the only source of rRNA genes in these strains is the pNK-encoded $r r n B$ operon, each strain will possess a homogeneous population of ribosomes containing mutant $23 \mathrm{~S}$ rRNA. The structures of the pNK-derivatives were verified by restriction digestion and resequencing the SacI/SphI region for each rRNA mutant strain of TA531.

\section{Purification of ribosomes and sequencing of rRNA}

Ribosomes were prepared from the Acinetobacter and E. coli strains by sonication and centrifugation, followed by rRNA extraction as previously described (Stern et al. 1988). The $23 \mathrm{~S}$ rRNA region around G745 was sequenced by extension with reverse transcriptase (Stern et al. 1988) from the primer mf11.

Methylation at G745 was measured using a modified version of the primer extension procedure devised by Ed Morgan's laboratory (Sigmund et al. 1988; Hansen et al. 2001). Briefly, $5^{\prime}-{ }^{32} \mathrm{P}-$ labeled sd33 primer (Table 2) was annealed to the G748-G763 region of the RNA and was extended with reverse transcriptase using a mixture of $100 \mu \mathrm{M}$ each of dATP, dCTP, and ddTTP. Extension terminates directly before G745 on methylated rRNA, or at A743 on unmethylated rRNA due to incorporation of the dideoxynucleotide. The degree of methylation was calculated from the relative intensities of the A743 and G745 bands on denaturing gels. 


\section{ACKNOWLEDGMENTS}

We are grateful to Jacob Poehlsgaard for making Figure 1, and we thank Lene Jakobsen for technical assistance with DNA sequencing. Dr. Elisabeth Pook is thanked for providing us with the $A$. calcoaceticus ADP1 strain and plasmid pWH845. We gratefully acknowledge support from the Danish Biotechnology Instrument Centre (DABIC), the European Commission's Fifth Framework Program (grant QLK2-CT2000-00935), and the Nucleic Acid Centre of the Danish Grundforskningsfond.

Received May 11, 2004; accepted July 23, 2004.

\section{REFERENCES}

Asai, T., Zaporojets, D., Squires, C., and Squires, C.L. 1999. An Escherichia coli strain with all chromosomal rRNA operons inactivated: Complete exchange of rRNA genes between bacteria. Proc. Natl. Acad. Sci. 96: 1971-1976.

Ban, N., Nissen, P., Hansen, J., Moore, P.B., and Steitz, T.A. 2000. The complete atomic structure of the large ribosomal subunit at $2.4 \AA$ resolution. Science 289: 905-920.

Björk, G. and Isaksson, L. 1970. Isolation of mutants of Escherichia coli lacking 5-methyluracil in transfer ribonucleic acid or 1-methylguanine in ribosomal RNA. J. Mol. Biol. 51: 83-100.

Bujard, H., Gentz, R., Lanzer, M., Stuber, D., Muller, M., Ibrahimi, I., Hauptle, M.T., and Dobberstein, B. 1987. A T5 promoter based transcription-translation system for the analysis of proteins in vivo and in vitro. Meth. Enzymol. 155: 416-433.

Bujnicki, J.M., Blumenthal, R.M., and Rychlewski, L. 2002. Sequence analysis and structure prediction of $23 \mathrm{~S}$ rRNA $\mathrm{m}^{1} \mathrm{G}$ methyltransferases reveals a conserved core augmented with a putative $\mathrm{Zn}$-binding domain in the $\mathrm{N}$-terminus and family-specific elaborations in the C-terminus. J. Mol. Micro. Biotechnol. 4: 93-99.

Cundliffe, E. 1989. How antibiotic-producing organisms avoid suicide. Annu. Rev. Microbiol. 43: 207-233.

Das, K., Acton, T., Chiang, Y., Shih, L., Arnold, E., and Montelione, G.T. 2004. Crystal structure of $\mathrm{RlmA} \mathrm{A}^{\mathrm{I}}$ : Implications for understanding the $23 \mathrm{~S}$ rRNA G745/G748-methylation at the macrolide antibiotic-binding site. Proc. Natl. Acad. Sci. 101: 40414046.

Decatur, W.A. and Fournier, M.J. 2003. RNA-guided nucleotide modification of ribosomal and other RNAs. J. Biol. Chem. 278: 695-698.

Douthwaite, S., Crain, P.F., Liu, M., and Poehlsgaard, J. 2004. The tylosin resistance methyltransferase $\mathrm{RlmA}^{\mathrm{II}}$ (TlrB) modifies the N-1 position of $23 \mathrm{~S}$ rRNA nucleotide G748. J. Mol. Biol. 337: 1073-1077.

Fouces, R., Mellado, E., Diez, B., and Barredo, J.L. 1999. The tylosin biosynthetic cluster from Streptomyces fradiae: Genetic organization of the left region. Microbiology 145: 855-868.

Gabashvili, I.S., Gregory, S.T., Valle, M., Grassucci, R., Worbs, M., Wahl, M.C., Dahlberg, A.E., and Frank, J. 2001. The polypeptide tunnel system in the ribosome and its gating in erythromycin resistance mutants of L4 and L22. Mol. Cell 8: 181-188.

Green, R. and Noller, H.F. 1996. In vitro complementatation analysis localizes $23 \mathrm{~S}$ posttranscriptional modifications that are required for Escherichia coli $50 \mathrm{~S}$ subunit assembly and function. RNA 2: 1011-1021.

Gregory, S.T. and Dahlberg, A.E. 1999. Erythromycin resistance mutations in ribosomal proteins L22 and L4 perturb the higher order structure of $23 \mathrm{~S}$ ribosomal RNA. J. Mol. Biol. 289: 827834.

Gustafsson, C. and Persson, B.C. 1998. Identification of the rrmA gene encoding the $23 \mathrm{~S}$ rRNA m1G745 methyltransferase in Escherichia coli and characterization of an m1G745-deficient mutant. J. Bacteriol. 180: 359-365.

Gutgsell, N.S., Campo, M.D., Raychaudhuri, S., and Ofengand, J. 2001. A second function for pseudouridine synthetases: A point mutant of RluD unable to form pseudouridines 1911, 1915 and 1917 in Escherichia coli 23S ribosomal RNA restores normal growth to a RluD-minus strain. RNA 7: 990-998.

Hansen, L.H., Kirpekar, F., and Douthwaite, S. 2001. Recognition of nucleotide G745 in $23 \mathrm{~S}$ ribosomal RNA by the RrmA methyltransferase. J. Mol. Biol. 310: 1001-1010.

Hansen, J.L., Ippolito, J.A., Ban, N., Nissen, P., Moore, P.B., and Steitz, T.A. 2002. The structures of four macrolide antibiotics bound to the large ribosomal subunit. Mol. Cell 10: 117128.

Harms, J., Schluenzen, F., Zarivach, R., Bashan, A., Gat, S., Agmon, I., Bartels, H., Franceschi, F., and Yonath, A. 2001. High resolution structure of the large ribosomal subunit from a mesophilic eubacterium. Cell 107: 679-688.

Higuchi, R., Krummel, B., and Saiki, R.K. 1988. A general method of in vitro preparation and specific mutagenesis of DNA fragments: Study of protein and DNA interactions. Nucleic Acids Res. 16: 7351-7367.

Ho, S.N., Hunt, H.D., Horton, R.M., Pullen, J.K., and Pease, L.R. 1989. Site-directed mutagenesis by overlap extension using the polymerase chain reaction. Gene 77: 51-59.

Juni, E. 1972. Interspecies transformation of Acinetobacter: Genetic evidence for a ubiquitous genus. J. Bacteriol. 112: 917-931.

Kagan, R.M. and Clarke, S. 1994. Widespread occurrence of three motifs in diverse S-adenosylmethionine-dependent methyltransferases suggests a common structure for these enzymes. Arch. Biochem. Biophys. 310: 417-427.

Kiss, T. 2002. Small nucleolar RNAs: an abundant group of noncoding RNAs with diverse cellular functions. Cell 109: 145-148.

Lafontaine, D.L., Preiss, T., and Tollevey, D. 1998. Yeast 18S RNA dimethylase Dimlp: A quality control mechanism in ribosome synthesis? Mol. Cell Biol. 18: 2360-2370.

Lebars, I., Yoshizawa, S., Stenholm, A.R., Guittet, E., Douthwaite, S., and Fourmy, D. 2003. Structure of 23S rRNA hairpin 35 and its interaction with the tylosin-resistance methyltransferase $\mathrm{RlmA} \mathrm{A}^{\mathrm{II}}$. EMBO J. 22: 183-192.

Liu, M. and Douthwaite, S. 2002a. Methylation at nucleotide G745 or G748 in 23S rRNA distinguishes Gram-negative from Gram-positive bacteria. Mol. Microbiol. 44: 195-204.

2002b. Resistance to the macrolide antibiotic tylosin is conferred by single methylations at 23S rRNA nucleotides G748 and A2058 acting in synergy. Proc. Natl. Acad. Sci. 99: 1465814663.

- 2002c. Activity of the ketolide antibiotic telithromycin is refractory to Erm monomethylation of bacterial rRNA. Antimicrob. Agents Chemother. 46: 1629-1633.

Liu, M., Kirpekar, F., van Wezel, G.P., and Douthwaite, S. 2000. The tylosin resistance gene $t l r B$ of Streptomyces fradiae encodes a methyltransferase that targets G748 in 23S rRNA. Mol. Microbiol. 37: $811-820$.

Mankin, A.S. 2001. Ribosomal antibiotics. Mol. Biol. 35: 509-520.

Nakatogawa, H. and Ito, K. 2002. The ribosomal exit tunnel functions as a discriminating gate. Cell 108: 629-636.

Ofengand, J. 2002. Ribosomal RNA pseudouridines and pseudouridine synthases. FEBS Lett. 514: 17-25.

Palmen, R., Vosman, B., Buijsman, P., Breek, C.K., and Hellingwerf, K.J. 1993. Physiological characterization of natural transformation in Acinetobacter calcoaceticus. J. Gen. Microbiol. 139: 295305.

Persson, B., Gustafsson, C., Berg, D.E., and Björk, G.R. 1992. The gene for a tRNA modifying enzyme, $\mathrm{m}^{5} \mathrm{U} 54$-methyltransferase, is essential for viability in Escherichia coli. Proc. Natl. Acad. Sci. 89: 39953998.

Rozenski, J., Crain, P.F., and McCloskey, J.A. 1999. The RNA Modification Database: 1999 update. Nucleic Acids Res. 27: 196-197. 


\section{Liu et al.}

Sambrook, J., Fritsch, E.F., and Maniatis, T. 1989. Molecular cloning: A laboratory manual. Cold Spring Harbor Laboratory Press, Cold Spring Harbor, NY.

Schirmer, F., Ehrt, S., and Hillen, W. 1997. Expression, inducer spectrum, domain structure, and function of MopR, the regulator of phenol degradation in Acinetobacter calcoaceticus NCIB8250. J. Bacteriol. 179: 1329-1336.

Schlünzen, F., Zarivach, R., Harms, J., Bashan, A., Tocilj, A., Albrecht, R., Yonath, A., and Franceschi, F. 2001. Structural basis for the interaction of antibiotics with the peptidyl transferase centre in eubacteria. Nature 413: 814-821.

Sigmund, C.D., Ettayebi, M., Borden, A., and Morgan, E.A. 1988. Antibiotic resistance mutations in ribosomal RNA genes of Escherichia coli. Meth. Enzymol. 164: 673-690.

Stern, S., Moazed, D., and Noller, H.F. 1988. Structural analysis of RNA using chemical and enzymatic probing monitored by primer extension. Meth. Enzymol. 164: 481-489.

Tenson, T. and Ehrenberg, M. 2002. Regulatory nascent peptides in the ribosomal tunnel. Cell 108: 591-594.

Weisblum, B. 1995. Erythromycin resistance by ribosome modification. Antimicrob. Agents Chemother. 39: 577-585.

Wilson, V. and Cundliffe, E. 1999. Molecular analysis of trrB, an antibiotic-resistance gene from tylosin-producing Streptomyces fradiae, and discovery of a novel resistance mechanism. J. Antibiot. 52: 288-296.

Xiong, L., Kloss, P., Douthwaite, S., Andersen, N.M., Swaney, S., Shinabarger, D.L., and Mankin, A.S. 2000. Oxazolidinone resistance mutations in $23 \mathrm{~S}$ rRNA of Escherichia coli reveal the central region of domain $\mathrm{V}$ as the primary site of drug action. J. Bacteriol. 182: 5325-5331.

Yanisch-Perron, C., Vieira, J., and Messing, J. 1985. Improved M13 phage cloning vectors and host strains: nucleotide sequences of the M13mp18 and pUC19 vectors. Gene 33: 103-119.

Yusupov, M.M., Yusupova, G.Z., Baucom, A., Lieberman, K., Earnest, T.N., Cate, J.H., and Noller, H.F. 2001. Crystal structure of the ribosome at $5.5 \AA$ resolution. Science 292: 883-896. 

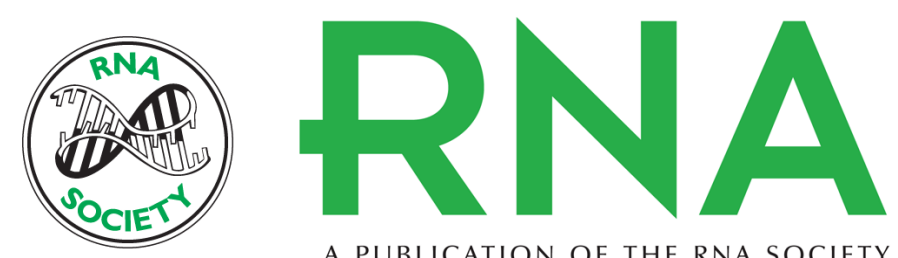

A PUBLICATION OF THE RNA SOCIETY

\section{Methylatign of 23S rRNA nucleotide G745 is a secondary function of the RImA methyltransferase}

MINGFU LIU, GUY W. NOVOTNY and STEPHEN DOUTHWAITE

RNA 2004 10: 1713-1720

References This article cites 45 articles, 16 of which can be accessed free at:

http://rnajournal.cshlp.org/content/10/11/1713.full.html\#ref-list-1

\section{License}

Email Alerting Receive free email alerts when new articles cite this article - sign up in the box at the Service top right corner of the article or click here. 